\title{
RECALL OF TYPE SPECIFIC ANTIBODIES IN MAN BY INJECTIONS OF STREPTOCOCCAL CELL WALLS*
}

\author{
By ELIZABETH V. POTTER, $†$ GENE H. STOLLERMAN and ALAN C. SIEGEL
}

\author{
(From the Departments of Medicine and Pediatrics, the Samuel J. Sackett Research Labora- \\ tory, Northwestern University Medical School, and the Streptococcal Research \\ Laboratory, Children's Memorial Hospital, Chicago, Ill.)
}

(Submitted for publication August 23, 1961 ; accepted October 19, 1961)

In the early part of this century several attempts were made to immunize human beings against beta hemolytic streptococci $(1-4)$. These attempts generally were considered to be unsuccessful. The results were difficult to evaluate, however, because of the multiplicity and toxicity of streptococcal antigens and the limited understanding of their relationship to virulence. Subsequently, immunity was correlated with antibody against type specific $M$ protein contained in streptococcal cell walls (5-9), and sensitive methods were developed for the assay of these type specific antibodies $(6,7)$.

Partially purified preparations of $\mathrm{M}$ protein were employed thereafter as vaccines $(10-15)$. Large doses proved antigenic in rabbits (10-11). Toxic reactions, however, limited vaccination in human beings to the administration of very small amounts of $\mathrm{M}$ protein. These quantities rarely provoked an immune response (12-15). Investigators, therefore, have been discouraged by the possibility that the amount of $M$ protein which can be tolerated in single doses may be below the threshold of antigenicity.

In the course of a controlled study of the immune response to streptococcal pharyngitis (16, 17), patients with infections of known serologic type have been observed for the development of type specific antibody. During the 4 years that this study has been in progress, type specific antibody has disappeared from the blood of approxi-

* This study was conducted under the sponsorship of the Commission on Streptococcal and Staphylococcal Diseases, Armed Forces Epidemiological Board, and was supported in part by the Office of the Surgeon General, Department of the Army, and by grants from the Chicago Heart Association and the Public Health Service (H-2622 and H-1890-C6).

$\dagger$ This investigation was conducted during the tenure of a traineeship, 2E-57, from the Institute of Allergy and Infectious Diseases, United States Public Health Service. mately half of the patients who initially developed immune response to their infections. Advantage was taken of this situation to determine whether or not small doses of streptococcal cell walls were sufficiently antigenic to recall antibody of homologous type. A positive outcome might encourage further attempts at primary immunization with similar preparations.

The following report will show that type specific antibody was readily recalled in human beings by the administration of small, well tolerated doses of vaccines prepared from streptococcal cell walls.

\section{METHODS}

Preparation of accine. Strain SF42 of type 12 streptococci was employed to prepare cell wall vaccine. This strain, originally isolated by Griffith in 1934 from a patient with scarlet fever (18), was supplied to us as a lyophilized culture by Dr. Rebecca Lancefield in 1956. At that time it contained a large amount of group A polysaccharide. After several mouse passages in this laboratory, it mutated to a variant which no longer contained group A antigen but, rather, the polysachharide designated " $V$ " (variant) antigen by McCarty and Lancefield (19). This strain was selected for preparation of the vaccine because large amounts of type $12 \mathrm{M}$ protein were present in the organisms and because the absence of group A polysaccharide was considered to be of possible advantage in reducing toxic reactions.

Type 5 cell wall vaccine was prepared with a group $\mathrm{A}$ strain, S1624, which had been isolated 2 years previously from a patient with pharyngitis at Children's Memorial Hospital, Chicago, Ill. Virulence and high $\mathrm{M}$ protein content had been maintained by frequent mouse passage.

Organisms for the preparation of vaccine were grown in 3-L lots of commercial Todd-Hewitt broth (Difco) which was modified by the addition of phosphate-buffered glucose (20) to contain approximately 1.5 per cent of the sugar. Cell walls then were prepared by the method of Barkulis and Jones (21) with minor modifications. Streptococci were harvested by centrifugation and washed 3 times in approximately $20 \mathrm{vol}$ of distilled water. The cells were then suspended in distilled water in a concentration of 10 per cent by wet weight.

Aliquots $(5 \mathrm{ml})$ of this suspension were agitated in 
a Mickle disintegrator with $5 \mathrm{mg}$ of no. 12 Ballotini glass beads. ${ }^{1}$ Each lot was examined microscopically to determine when fragmentation of the cells had occurred. A period of 20 minutes in the distintegrator at an amplitude of approximately $1.5 \mathrm{~cm}$ and a frequency of 60 times a second usually was adequate. The beads were removed from the cell walls by means of a coarse fritted glass filter. The cell walls then were centrifuged at 16,000 $\mathrm{G}$ for 30 minutes at $4^{\circ} \mathrm{C}$, resuspended in approximately

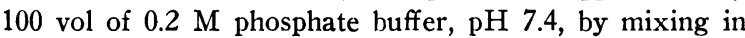
a Waring Blendor for 30 seconds, and centrifuged again at $16,000 \mathrm{G}$ for 30 minutes. The cell walls were washed in this fashion five times in phosphate buffer and a sixth time in distilled water. They were finally suspended in $100 \mathrm{ml}$ of pyrogen-free, normal saline with 0.9 per cent benzyl alcohol, autoclaved at 15 pounds of pressure for 15 minutes, quickly frozen in a dry ice-alcohol bath and stored at $-70^{\circ} \mathrm{C}$ as stock vaccine.

One-ml aliquots of these stock suspensions were found to contain 3 to $4.5 \mathrm{mg}$ of cell walls by dry weight and 218 to $276 \mu \mathrm{g}$ of nitrogen by micro-Kjeldahl analysis. Dilutions containing the desired amounts of cell wall nitrogen were made from these stock suspensions and tested for sterility shortly before their use in vaccination.

$M$ protein and group specific carbohydrate were extracted from $1-\mathrm{ml}$ aliquots of vaccine by the method of Swift, Wilson and Lancefield (22). The resulting extracts reacted strongly ( 3 to 4 plus) with homologous antisera to type 12 and type $5 \mathrm{M}$ proteins, respectively, and less strongly with antisera to the variant and group A carbohydrates, respectively. Ultraviolet absorption spectra of these extracts also were studied to determine to what extent the cell walls had been freed from nucleoproteins. The relative concentration of nucleic acid to protein in the extracts varied from 5 to 8 per cent as determined by the ratio of the optical densities at 2,800 and $2,600 \AA(23)$.

Immunization procedurc. Vaccine was administered to patients selected from a controlled study of streptococcal pharyngitis in progress at Children's Memorial Hospital since 1956. The protocol of this study has been described in detail elsewhere (16). Intradermal skin tests with cell wall suspensions containing at least $0.05 \mu \mathrm{g}$ nitrogen were made in all patients prior to vaccination. The sites were examined for reactions at 30 hours. Patients with induration or erythema of more than $1 \mathrm{~cm}$ in diameter were not vaccinated. When no induration or erythema was present, 50 times the skin test dose was administered subcutaneously. When induration or erythema of $1 \mathrm{~cm}$ or less was noted, 10 times the skin test dose was given subcutaneously. Subsequent weekly injections, with increments of 2 to 5 times the previous dose, were administered according to each patient's tolerance. The total subcutaneous dose, therefore, varied with each individual and ranged from 8 to $56 \mu \mathrm{g}$ of cell wall nitrogen. In 8 patients all injections of vaccine were administered intradermally. These patients received 1 to $7 \mu \mathrm{g}$ of cell wall nitrogen divided into 4 or 5 injections.

\footnotetext{
${ }^{1}$ C. O. Brinkmann \& Co., Great Neck, N. Y.
}

At the first visit the patient was examined, his throat was cultured, and blood was drawn for type specific antibody determination. Throat cultures were made at each subsequent visit to exclude the possibility that unapparent streptococcal infections, rather than vaccine, might boost antibody titers. Blood was drawn again for type specific antibody assay 1 week after the last injection.

Assay of sera for type specific antibody. Type specific antibody titer was determined by two methods used routinely in this laboratory-the bactericidal test modified slightly from that described by Lancefield (24), and the long chain test described by Stollerman and Ekstedt (25). A positive bactericidal test depended upon opsonization of the streptococci by immune serum and their subsequent phagocytosis by the normal control blood. The bactericidal index was used as an expression of the opsonic activity of antibody to $M$ protein (24). This was derived by comparing the growth rates of virulent streptococci in "normal" human blood, which contained no homologous type specific antibody, with the same blood to which the test serum was added. An index of 100, for example, indicated that growth was 100 times greater in the control blood than in the same blood to which the test serum was added. Bactericidal indices of less than 10 were not considered significant, 10 to 25 were considered to be due to traces of $\mathrm{M}$ antibody, 25 to 100 were weakly positive, 100 to 500 positive, and greater than 500 strongly positive.

The chain length index was derived from the ratio of the mean chain length of streptococci grown in the test serum to the mean chain length of the same organisms grown in normal rabbit serum. Because virulent encapsulated streptococci grow in long chains in the presence of homologous type antiserum, and in very short chains in serum which does not contain type specific antibody, this index is a semiquantitative expression for the amount of anti-M antibody in the system. A threefold increase in mean chain length (index $=3$ ), or greater, was considered a statistically significant test for type specific antibody $(26,27)$.

During these studies, it became apparent that the many variables of the bactericidal and long chain tests were particularly important in assays of sera in which type specific antibody was present in very low titer. The size of the inoculum was critical. Dilutions containing 10 to 150 organisms in $0.1 \mathrm{ml}$ broth were optimal inocula for the demonstration of small amounts of type specific antibody by the bactericidal test. When heavier suspensions were employed, the extracellular streptococci multiplied rapidly and obscured the opsonic effect of the antiserum. A minimal inoculum of approximately 10,000 organisms was required in the long chain test in order to count sufficient numbers of streptococci conveniently. Thus, a larger amount of antibody was necessary to demonstrate long chain growth. At critical levels, therefore, the bactericidal test could be positive and the long chain test negative. Occasionally, the reverse situation could occur due to nonspecific factors affecting phagocytosis $(26,27)$. 
TABLE I

Effect of virulence of test organism of type 12 streptococci upon bactericidal and long chain tests for type specific antibody when serum titers are low

\begin{tabular}{|c|c|c|c|c|}
\hline Serum & $\begin{array}{c}\text { Strain } \\
\text { virulence } \\
\text { (T12 SF42) }\end{array}$ & $\begin{array}{l}\text { Bactericidal } \\
\text { index* }\end{array}$ & $\begin{array}{l}\text { Mean chain } \\
\text { length }\end{array}$ & $\begin{array}{l}\text { Chain length } \\
\text { indext }\end{array}$ \\
\hline Normal human (T12 antibody absent) & $\begin{array}{l}\text { Moderate } \\
\text { Highf }\end{array}$ & $\begin{array}{l}1 \\
1\end{array}$ & $\begin{array}{l}9 \\
3\end{array}$ & $\begin{array}{l}1 \\
1\end{array}$ \\
\hline \multicolumn{5}{|l|}{ T12 human convalescent (low titer) $\S$} \\
\hline $\begin{array}{l}\text { Patient A } \\
\text { Patient B }\end{array}$ & $\begin{array}{l}\text { Moderate } \\
\text { High } \\
\text { Moderate } \\
\text { High }\end{array}$ & $\begin{array}{r}2,960 \\
360 \\
740 \\
1\end{array}$ & $\begin{array}{r}45 \\
7 \\
18 \\
6\end{array}$ & $\begin{array}{l}5 \\
2 \\
2 \\
2\end{array}$ \\
\hline T12 hyperimmune rabbit (high titer) $\|$ & $\begin{array}{l}\text { Moderate } \\
\text { High }\end{array}$ & $\begin{array}{r}2,960 \\
11,000\end{array}$ & $\begin{array}{r}107 \\
65\end{array}$ & $\begin{array}{l}12 \\
22\end{array}$ \\
\hline
\end{tabular}

* Bactericidal indices of less than 10 are not considered significant; 10 to $25=$ traces of $\mathrm{M}$ antibody; 25 to $100=$ weakly positive; 100 to $500=$ positive $; 500=$ strongly positive (see text).

$\dagger$ Long chain index $=$ ratio of mean chain length of streptococci grown in test serum to that of streptococci grown in normal serum. An index of 3 or greater is considered a positive test for type specific antibody.

$\ddagger$ Same strain after 4 daily passages through fresh human blood (see text).

\$Strongly positive tests demonstrable only with undiluted serum and strains of moderate virulence. Tests became negative when serum was diluted $1: 4$ (Patient A) and 1:2 (Patient B).

|| Strongly positive tests demonstrable with serum diluted 1:50 and strains of maximal virulence.

The degree of virulence of the test strain of streptococci also had an effect on the resulting indices when titers of serum antibody were low (Table I). Similar observations on bactericidal tests (28) and on long chain tests (27) have been reported by others. Organisms of moderate virulence were required for assay of low levels of type specific antibody, but were difficult to maintain in this phase. Two or three passages of virulent type 12 streptococci through Todd-Hewitt broth frequently resulted in dissociation of the strain to an avirulent phase. In contrast, highly virulent organisms emerged after daily passage through mice or through fresh human blood which was rotated for 4 hours at $37^{\circ} \mathrm{C}$. Organisms were maintained in an intermediate phase of virulence by alternating these procedures.

Finally, considerable variation of the phagocytic activity of human blood from different individuals against encapsulated strains was encountered, as previously described $(24,29)$. Donors were selected, therefore, from a small group of adults whose bloods were known to produce satisfactory tests.

Because of the above variables, assays of type specific antibody in sera obtained from serial bleedings of the same patients were always made simultaneously in the same experiment. Changes in titer were confirmed by repeated experiments.

\section{RESULTS}

Assay of vaccine by recall of type specific antibody in rabbits. Five rabbits were immunized with heat-killed, whole cell, type 12 streptococcal vaccine administered intravenously three times a week for 6 weeks. Two weeks after the last injection, type specific antibody was present in all animals. The titers decreased to very low levels during the next 8 months. One subcutaneous in-

TABLE II

Primary immunization and recall of type specific antibodies in rabbits

\begin{tabular}{|c|c|c|c|c|c|c|}
\hline \multirow[b]{2}{*}{$\begin{array}{c}\text { Rabbit } \\
\text { no. }\end{array}$} & \multicolumn{3}{|c|}{ Bactericidal index* } & \multicolumn{3}{|c|}{ Chain length index* } \\
\hline & $\begin{array}{l}\text { Primary } \\
\text { responsef }\end{array}$ & 8 months & $\begin{array}{l}\text { Secondary } \\
\text { response }\end{array}$ & $\begin{array}{l}\text { Primary } \\
\text { response }\end{array}$ & 8 months & $\begin{array}{l}\text { Secondary } \\
\text { response }\end{array}$ \\
\hline $\begin{array}{l}1 \\
2 \\
3 \\
4 \\
5\end{array}$ & $\begin{array}{r}2,560 \\
512 \\
320 \\
2,560 \\
320\end{array}$ & $\begin{array}{l}43 \\
16 \\
10 \\
28 \\
20\end{array}$ & $\begin{array}{r}600 \\
1,520 \\
360 \\
360 \\
252\end{array}$ & $\begin{array}{r}6 \\
6 \\
7 \\
14 \\
8\end{array}$ & $\begin{array}{l}2 \\
1 \\
1 \\
2 \\
4\end{array}$ & $\begin{array}{r}26 \\
26 \\
8 \\
14 \\
21\end{array}$ \\
\hline
\end{tabular}

* See footnotes, Table I.

† After 6 week course of heat-killed whole cell vaccine i.v. totaling approximately $8 \mathrm{mg}$ of whole cell nitrogen.

$\ddagger$ After one injection of cell walls containing $0.08 \mathrm{mg}$ of cell wall nitrogen. 
jection of $0.5 \mathrm{ml}$ of a saline suspension of type 12 cell walls containing $80 \mu \mathrm{g}$ of nitrogen was then given to each animal. Blood drawn 5 days later was assayed for type specific antibody (Table II). A definite increase in titer was demonstrated in each rabbit. The secondary nature of the immune response in these animals was confirmed by the failure of the same dose of vaccine to elicit measurable type 12 antibody response in five normal rabbits. Furthermore, antibodies did not appear in the control animals after two additional injections of the same dose of the vaccine.

Assay of human tolerance to cell wall vaccine. Skin tolerance to the cell walls was evaluated in normal adults. Erythema and induration ( 1 to 3.5 $\mathrm{cm}$ ) was present 30 hours after the intracutaneous injection of $0.05 \mu \mathrm{g}$ cell wall nitrogen in 7 of the 18 individuals tested. Thirty children received 0.05 to $0.25 \mu \mathrm{g}$ cell wall nitrogen intracutaneously. Six developed local erythema and induration of 1 to $2 \mathrm{~cm}$ in diameter which persisted for 30 hours.

Tolerance to subcutaneous injections of larger

TABLE III

Decline in human type specific antibody titers after type 12 infections

\begin{tabular}{|c|c|c|c|}
\hline $\begin{array}{l}\text { Case } \\
\text { no. }\end{array}$ & $\begin{array}{c}\text { Months } \\
\text { after } \\
\text { infection }\end{array}$ & $\begin{array}{l}\text { Bactericidal } \\
\text { index* }\end{array}$ & $\begin{array}{l}\text { Chain } \\
\text { length } \\
\text { index* }\end{array}$ \\
\hline 1 & $\begin{array}{r}2 \\
20\end{array}$ & $\begin{array}{r}3,389 \\
1\end{array}$ & $\underset{1}{\mathrm{ND} \dagger}$ \\
\hline 2 & $\begin{array}{r}3 \\
18\end{array}$ & $\begin{array}{r}4,626 \\
51\end{array}$ & $\begin{array}{l}3 \\
1\end{array}$ \\
\hline 3 & $\begin{array}{r}5 \\
18\end{array}$ & $\begin{array}{r}512 \\
1\end{array}$ & $\begin{array}{l}4 \\
1\end{array}$ \\
\hline 4 & $\begin{array}{r}2 \\
18\end{array}$ & $\begin{array}{r}6,400 \\
1\end{array}$ & $\begin{array}{l}4 \\
2\end{array}$ \\
\hline 5 & $\begin{array}{r}6 \\
18\end{array}$ & $\begin{array}{r}400 \\
20\end{array}$ & $\begin{array}{l}2 \\
1\end{array}$ \\
\hline 6 & $\begin{array}{r}2 \\
13\end{array}$ & $\begin{array}{r}320 \\
1\end{array}$ & $\begin{array}{l}8 \\
1\end{array}$ \\
\hline 7 & 18 & $\begin{array}{r}2,112 \\
1\end{array}$ & $\begin{array}{r}\text { ND } \\
1\end{array}$ \\
\hline 8 & $\begin{array}{r}7 \\
36\end{array}$ & $\begin{array}{r}3,390 \\
400\end{array}$ & $\begin{array}{r}36 \\
1\end{array}$ \\
\hline 9 & $\begin{array}{r}6 \\
12\end{array}$ & $\begin{array}{r}26 \\
1\end{array}$ & $\begin{array}{l}4 \\
1\end{array}$ \\
\hline 10 & $\begin{array}{l}2 \\
6\end{array}$ & $\begin{array}{r}5,760 \\
1\end{array}$ & $\begin{array}{l}2 \\
2\end{array}$ \\
\hline
\end{tabular}

* See footnotes, Table I.

$\dagger$ Not done doses of vaccine was then studied in normal adults. Three individuals whose skin tests were negative received doses of $2.5,25$, and $50 \mu \mathrm{g}$ of cell wall nitrogen, respectively. The first subject had no reaction. The second had slight erythema and induration at the injection site, slight malaise, and fever of $100^{\circ} \mathrm{F}$. The recipient of $50 \mu \mathrm{g}$ nitrogen developed marked local swelling and tenderness, regional lymphadenitis, fever, and malaise. The vaccine, therefore, was administered subsequently to children in small divided doses which were increased according to the individual's tolerance. This procedure required a series of 2 to 4 injections, spaced weekly, instead of a single booster dose. Reactions in the children were limited to transient local tenderness, erythema, and induration. Children who received 15 to $30 \mu \mathrm{g}$ nitrogen subcutaneously in one dose usually developed painless, discrete induration at the site of injection which was often palpable 1 week later. These nodules rarely exceeded $1 \mathrm{~cm}$ in diameter and were of no clinical consequence. General reactions such as fever and malaise were absent or mild.

Skin tests were repeated 1 year after vaccination in eight patients. The reaction in five patients was unchanged. An increase in induration of 1 to $2 \mathrm{~cm}$ was observed in three individuals. Two of these subjects had received the vaccine intracutaneously.

Immune response to cell wall vaccine in normal adults. The three adults who were studied for tolerance to vaccine served also as subjects for a pilot study of the immune response to the vaccine doses employed. The individual who received $50 \mu \mathrm{g}$ cell wall nitrogen had type 12 antibody in low titer before the injection. The titer increased markedly 1 week after the single dose of vaccine. In contrast, the subject who received $25 \mu \mathrm{g}$ cell wall nitrogen had no antibody before or after his booster injection. The third individual received $2.5 \mu \mathrm{g}$ of vaccine nitrogen. The titer of type 12 antibody was high before vaccination and increased only slightly after the very small booster dose of cell walls. The responses of these individuals suggested, therefore, that the desired booster dose for human beings might be between 25 and $50 \mu \mathrm{g}$ of cell wall nitrogen.

Immune response to cell wall vaccine in children in whom type specific antibody had previously 
TABLE IV

Recall of type specific antibodies by cell wall vaccine administered to patients previously immunized by type 12 streptococcal pharyngitis *

\begin{tabular}{|c|c|c|c|c|c|c|c|}
\hline \multirow[b]{2}{*}{$\begin{array}{c}\text { Patient } \\
\text { no. }\end{array}$} & \multirow{2}{*}{$\begin{array}{c}\text { Vaccine } \\
\text { dose } \\
(\mu \mathrm{g} \mathrm{N})\end{array}$} & \multicolumn{3}{|c|}{ Bactericidal index $†$} & \multicolumn{3}{|c|}{ Chain length indext } \\
\hline & & $\begin{array}{c}\text { After } \\
\text { infection }\end{array}$ & $\begin{array}{c}\text { Before } \\
\text { vaccine }\end{array}$ & $\begin{array}{c}\text { After } \\
\text { vaccine }\end{array}$ & $\begin{array}{c}\text { After } \\
\text { infection }\end{array}$ & $\begin{array}{c}\text { Before } \\
\text { vaccine }\end{array}$ & $\begin{array}{c}\text { After } \\
\text { vaccine }\end{array}$ \\
\hline 1 & 14 & 3,389 & 1 & 2,000 & $\mathrm{ND}+$ & 1 & 3 \\
\hline 2 & 44 & 4,626 & 40 & 5,500 & $3^{+}$ & 1 & 3 \\
\hline 3 & 4 & 512 & 1 & 400 & 4 & 1 & 3 \\
\hline 4 & 42 & 6,400 & 1 & 17,000 & 4 & 1 & 2 \\
\hline 5 & 42 & 400 & 13 & 5,500 & 2 & 2 & 1 \\
\hline 6 & 42 & 320 & 4 & 14,000 & 8 & 1 & 3 \\
\hline 7 & 44 & 2,112 & 1 & 3,700 & ND & 1 & 2 \\
\hline 8 & 16 & 3,390 & 400 & 1,400 & 36 & 6 & 5 \\
\hline 9 & 8 & 26 & 1 & 3,000 & 4 & 1 & 6 \\
\hline 10 & 7 & 5,760 & 3 & 1,730 & 2 & 2 & 2 \\
\hline
\end{tabular}

* Patients are the same as those listed in Table III.

† See footnotes, Table I.

$\ddagger$ Not done.

been demonstrated after infection. Ten children were selected who had formerly developed unmistakable type 12 antibody responses after type 12 streptococcal pharyngitis, but in whom the titer of this antibody subsequently disappeared (seven patients) or diminished considerably (three patients) during the following 2 years (Table III).

Type 12 antibody was recalled or boosted in all of these patients after doses of 4 to $44 \mu \mathrm{g}$ cell wall nitrogen, given in three or four injections at weekly intervals (Table IV). Antibody appeared within 3 weeks from the onset of the course of injections and was found to be type specific when tested with heterologous organisms. When tested by serial dilutions of the sera, the post-vaccination titers were equal to or greater than the titers which had followed the natural infections. The recalled antibodies decreased to prevaccination levels within 6 months. Patient 8 in Table IV was the sole exception to the above observations. In this patient, antibody was still present in relatively high titer at the time of vaccination. Antibody levels increased only slightly after vaccination. The titer was still increased 6 months later.

Immune response to cell wall vaccine in patients with previous streptococcal infections followed by little or no demonstrable type specific antibody. A group of ten patients was selected to explore the possibility that their previous infections might have provoked primary immune responses even though these could not be demon-

TABLE V

Effect of cell wall vaccination on patients who had antecedent T12 or T5 infections which had been followed by feeble or undetectable type specific immune responses

\begin{tabular}{|c|c|c|c|c|c|c|c|c|}
\hline \multirow[b]{2}{*}{$\begin{array}{l}\text { Patient } \\
\text { no. }\end{array}$} & \multirow[b]{2}{*}{$\begin{array}{c}\text { Antecedent } \\
\text { infection }\end{array}$} & \multirow[b]{2}{*}{$\begin{array}{c}\text { Vaccine } \\
\text { dose } \\
(\mu \mathrm{g} \mathrm{N})\end{array}$} & \multicolumn{3}{|c|}{ Bactericidal index* } & \multicolumn{3}{|c|}{ Chain length index* } \\
\hline & & & $\begin{array}{c}\text { After } \\
\text { infection } \dagger\end{array}$ & $\begin{array}{c}\text { Before } \\
\text { vaccine }\end{array}$ & $\begin{array}{c}\text { After } \\
\text { vaccine }\end{array}$ & $\begin{array}{c}\text { After } \\
\text { infection } \dagger\end{array}$ & $\begin{array}{r}\text { Before } \\
\text { vaccine }\end{array}$ & $\begin{array}{c}\text { After } \\
\text { vaccine }\end{array}$ \\
\hline 11 & $\mathrm{~T} 12$ & 5 & 39 & 7 & $7,500 \ddagger$ & 2 & 2 & 2 \\
\hline 12 & T5 & 40 & 17 & 14 & $7,184 \ddagger$ & 1 & 2 & $6 \neq$ \\
\hline 13 & $\mathrm{~T} 12$ & 44 & 9 & 3 & $7,680 \ddagger$ & 2 & 1 & 1 \\
\hline 14 & $\mathrm{~T} 12$ & 6 & 3 & 3 & $480 \ddagger$ & 3 & 1 & 1 \\
\hline 15 & $\mathrm{~T} 12$ & 5 & 3 & 1 & 3 & 1 & 1 & 1 \\
\hline 16 & $\mathrm{~T} 5$ & 40 & 3 & 1 & 2 & 2 & 1 & 2 \\
\hline 17 & $\mathrm{~T} 5$ & 39 & 1 & 4 & $25 \ddagger$ & 3 & 1 & $7 \ddagger$ \\
\hline 18 & T5 & 39 & 1 & 3 & $713 \ddagger$ & 1 & 2 & $7 \ddagger$ \\
\hline 19 & $\mathrm{~T} 12$ & 5 & 1 & 1 & $1^{+}$ & 1 & 2 & $2^{+}$ \\
\hline 20 & $\mathrm{~T} 12$ & 44 & 1 & 4 & 4 & 1 & 1 & 1 \\
\hline
\end{tabular}

* See footnotes, Table I.

$\dagger$ Probable traces of type specific antibody present after infection are italicized.

‡ Significant immune response after vaccination. 
TABLE VI

Effect of cell wall vaccination of patients who had no known antecedent T12 infections and whose sera before vaccination showed little or no T12 antibody

\begin{tabular}{|c|c|c|c|c|c|}
\hline \multirow[b]{2}{*}{$\begin{array}{c}\text { Patient } \\
\text { no. }\end{array}$} & \multirow{2}{*}{$\begin{array}{c}\text { Vaccine } \\
\text { dose } \\
(\mu \mathrm{g} \mathrm{N})\end{array}$} & \multicolumn{2}{|c|}{ Bactericidal index* } & \multicolumn{2}{|c|}{ Chain length index* } \\
\hline & & $\begin{array}{c}\text { Before } \\
\text { vaccine† }\end{array}$ & $\begin{array}{c}\text { After } \\
\text { vaccine }\end{array}$ & $\begin{array}{c}\text { Before } \\
\text { vaccine† }\end{array}$ & $\begin{array}{c}\text { After } \\
\text { vaccine }\end{array}$ \\
\hline 21 & 56 & 15 & $1,000 \ddagger$ & 5.0 & 5.2 \\
\hline 22 & 16 & 10 & $7,680 \ddagger$ & 1.0 & 1.4 \\
\hline 23 & 56 & 10 & $1,900 \ddagger$ & 0.8 & 1.1 \\
\hline 24 & 30 & 3 & $2,560 \ddagger$ & 2.8 & 1.3 \\
\hline 25 & 3 & 1 & $324 \ddagger$ & 3.6 & $5.0 \ddagger$ \\
\hline 26 & 22 & 4 & 1 & 1.0 & 1.0 \\
\hline 27 & 18 & 1 & 1 & 2.2 & 2.0 \\
\hline 28 & 49 & 1 & 1 & 1.8 & 2.1 \\
\hline 29 & 56 & 1 & $30 \ddagger$ & 1.6 & $5.9 \pm$ \\
\hline 30 & 38 & 1 & $1^{+}$ & 1.0 & $2.0^{+}$ \\
\hline 31 & $1 \S$ & 1 & 1 & 1.5 & 2.0 \\
\hline 32 & $5 \S$ & 1 & 1 & 1.3 & 2.6 \\
\hline 33 & 13 & 2 & 2 & 0.8 & 1.0 \\
\hline 34 & 45 & 1 & 3 & 1.8 & 3.67 \\
\hline
\end{tabular}

* See footnotes, Table I.

¥ Significant immune response after vaccination.

$\S$ Vaccine administered intracutaneously rather than subcutaneously.

strated convincingly by assays of convalescent sera for type specific antibody. It was considered that booster vaccination might reveal whether or not primary immunization had occurred during the antecedent infection.

Of this group of patients, six had been infected previously with type 12 , and four with type 5 organisms. Unmistakable amounts of type specific antibodies appeared within 3 weeks of the first injection of homologous cell walls in six of the ten patients (Table V). Of the six in whom antibody levels were boosted, five had shown postinfection titers which were interpreted as probable traces of type specific antibody by one of the two methods employed. The remaining patient (Patient 18, Table V) showed an unmistakable

TABLE VII

Response of patients to cell wall vaccines

\begin{tabular}{llccc}
\hline \hline $\begin{array}{c}\text { Previous } \\
\text { infection }\end{array}$ & $\begin{array}{l}\text { Primary } \\
\text { response }\end{array}$ & $\begin{array}{c}\text { No. of } \\
\text { patients }\end{array}$ & $\begin{array}{c}\text { Cell } \\
\text { walls }\end{array}$ & $\begin{array}{c}\text { Secondary } \\
\text { response }\end{array}$ \\
\hline T12 & $\begin{array}{l}\text { Positive } \\
\text { Trace }\end{array}$ & 10 & $\mathrm{~T} 12$ & 10 \\
& Negative & 3 & & 3 \\
& Total & 16 & & 13 \\
T5 & Trace & 2 & T5 & 2 \\
& Negative & 2 & & 1 \\
& Total & 4 & & 3 \\
Unknown & Trace* & 5 & T12 & 5 \\
& Negative & 9 & & 2 \\
& Total & 14 & & 7 \\
\hline
\end{tabular}

* Trace of $\mathrm{T} 12$ antibody present in serum before vaccination; previous infection not documented. immune response by bactericidal and long chain tests after vaccination, despite the apparent absence of type 5 serum antibody after his natural infection.

Immune responses to type 12 cell walls in patients with no previously documented type 12 infections and with type 12 antibody present in trace amounts or absent. These patients were studied for two reasons: to determine the incidence of antibody recall in a "normal population" thought to be free of recent type 12 infections, and to obtain suitable candidates for a future study of primary immunization from among those failing to demonstrate secondary responses. Of 22 healthy individuals studied in this group, 4 (18 per cent) were found to have definitely positive tests for type 12 antibodies. Of the remainder, vaccination with type 12 cell walls was accomplished in 14 (Table VI). Of the 14, 4 individuals (Patients 21, 22, 23 and 25) had possible traces of type 12 antibody, as evidenced by minimal values for either bactericidal or long chain tests. In a fifth individual (Patient 24) the long chain index was almost 3, the lower limit accepted for a significant test. Type 12 antibodies were recalled in 7 of these 14 patients. These 7 included the 5 patients mentioned who had probable traces of antibody before immunization, and an additional 2 patients (Patients 29 and 34) in whom type 12 antibodies had not been detectable previously.

The relationship between the evidence for ante- 
cedent primary immunization by natural infection and subsequent booster responses to vaccine is summarized in Table VII. It appeared that in all instances in which type specific antibody was thought to be present in definite or trace amounts, vaccination resulted in a significant secondary immune response.

Type specificity of recall by cell wall vaccine. Three children who had had prior type 3 infections followed by the appearance of type 3 antibody were given type 12 cell wall vaccine. After vaccination the titer of type 3 antibodies decreased in two of these individuals and remained very low in the third. Type 12 antibody appeared in two of these patients although they were known not to have had type 12 antibody prior to vaccination.

The specificity of both natural and artificial immunization was demonstrated in two representative cases (Table VIII). The first patient had a low titer of type 3 antibody after type 3 pharyngitis. This disappeared 2 years later. Vaccination with type 12 cell walls at this time was followed by type 12 antibodies without reappearance of type 3 antibody. The second patient had naturally acquired type 12 antibody which decreased during 2 years of observation. She subsequently contracted a type 3 infection. Soon thereafter type 3 antibody appeared in strong titer whereas type 12 antibody did not increase. Subsequent vaccination with type 12 cell walls boosted type 12 but not type 3 antibodies.

\section{DISCUSSION .}

Type specific antibody was readily recalled in all of the vaccinated patients who were known to have been immunized naturally by previous infection with group A streptococci of homologous type. The type specific immune responses observed in the other subjects of this study were also considered secondary rather than primary in nature because of the small doses of cell walls employed as antigen and the relatively short period of time between vaccination and the appearance of antibody. The total amount of nitrogen administered was 5 to $44 \mu \mathrm{g}$, of which only a portion (approximately one-third) probably represented $M$ protein (21). Three times the largest amount of cell walls given to these patients failed to stimulate the primary appearance of type specific antibody in rabbits. Furthermore, others have not been able to elicit regularly a primary response in human beings with similar preparations in larger doses $(14,15)$.

The consistency of recall in the subjects known to have had type specific antibody at an earlier date indicates that the $M$ protein contained in well tolerated doses of streptococcal cell walls is antigenic for human beings and that type specific immunity can be boosted artificially. This ability to respond rapidly to very small antigenic stimuli probably indicates some degree of immunity to homologous types of group A streptococci, even in those human beings whose bloods do not contain demonstrable type specific antibody.

In contrast to recall after vaccination, a primary type specific immune response to a natural group A streptococcal infection seems to require prolonged antigenic stimulation. Type specific antibody rarely appears earlier than 35 to 60 days after the onset of symptoms in natural infections. The

TABLE VIII

Type specificity of antibody responses to natural infections and to cell wall vaccine

\begin{tabular}{|c|c|c|c|c|c|c|}
\hline \multirow[b]{3}{*}{ Case } & \multirow[b]{3}{*}{ Date } & \multirow[b]{3}{*}{ Antigenic stimulus } & \multicolumn{4}{|c|}{ Type specific antibody } \\
\hline & & & \multicolumn{2}{|c|}{ Bactericidal index* } & \multicolumn{2}{|c|}{ Chain length index* } \\
\hline & & & Type 12 & Type 3 & Type 12 & Type 3 \\
\hline 740 & $\begin{array}{l}\text { Nov, } 1957 \\
\text { Apr, } 1960 \\
\text { May, } 1960\end{array}$ & $\begin{array}{l}\text { T3 pharyngitis } \\
\text { None (follow-up) } \\
\text { T12 vaccine }\end{array}$ & $\begin{array}{r}\mathrm{ND} \ddagger \\
3 \\
2,560\end{array}$ & $\begin{array}{r}71 \\
1 \\
1\end{array}$ & $\begin{array}{c}\text { ND } \\
1 \\
3\end{array}$ & $\begin{array}{l}1 \\
1 \\
1\end{array}$ \\
\hline 540 & $\begin{array}{l}\text { Apr, } 1957 \\
\text { Feb, 1959 } \\
\text { Oct, 1959 } \\
\text { Nov, } 1959\end{array}$ & $\begin{array}{l}\text { T12 pharyngitis } \\
\text { None (follow-up) } \\
\text { T3 pharyngitis } \\
\text { T12 vaccine }\end{array}$ & $\begin{array}{r}12,000 \\
24 \\
13 \\
5,500\end{array}$ & $\begin{array}{r}\text { ND } \\
2 \\
6,096 \\
6,096\end{array}$ & $\begin{array}{l}2 \\
1 \\
1 \\
2\end{array}$ & $\begin{array}{l}\text { ND } \\
1 \\
15 \\
11\end{array}$ \\
\hline
\end{tabular}

* See footnotes, Table I.

$\dagger$ Not done. 
appearance of the antibody correlates closely with the duration of convalescent carriage of group A streptococci (17). Moreover, the development of type specific antibody is markedly suppressed by effective therapy which promptly terminates pharyngeal carriage of the organisms $(17,30,31)$.

Attempts have been made by others to achieve primary type specific immunization in human beings by relatively prolonged antigenic stimulation with $\mathrm{M}$ protein. Cell walls have been administered over periods of 3 months to 1 year to 52 adults (14) and acid-extracted $M$ protein in aluminum phosphate adjuvant has been given monthly for six injections to 22 children (15). Type specific antibody appeared in only six of the former and two of the latter group. These may well have represented secondary responses. However, primary stimulation of antibody may require a more sustained exposure of the subject to $M$ protein, or a larger total dose than has been administered. Secondary immune responses to vaccines in the subjects of the present study whose primary type specific responses were of very low titer, or not demonstrable by our methods of assay, should encourage further attempts at primary immunization by repeated courses of injections of cell walls by various schedules.

Furthermore, the possibility of immunization with cell walls of multiple types of streptococci seems reasonable. In these studies, type 5 antibody appeared to be recalled as readily as type 12 . Other investigators have achieved primary immunization in rabbits with cell walls of types 14 and $19(11,14)$. The prevalence, however, of type 12 streptococci as a cause of sporadic infections among civilian populations $(16,32,33)$, the frequent association of organisms of this serotype with acute glomerulonephritis (34), and their association with other serious illnesses $(35,36)$ might make immunization against type 12 organisms alone valuable in preventing a significant amount of streptococcal disease.

The consistency of type specific antibody recall by cell wall vaccines in patients naturally immunized with streptococci also suggests a sensitive method for determining the frequency of previous infection with a given streptococcal serotype. Type specific antibody may decrease below the threshold of sensitivity of the bactericidal test in a relatively short time after its appearance. For example, after mild sporadic streptococcal disease in Chicago school children, 65 per cent of patients who developed a type specific immune response no longer had detectable antibody 2 years later (17). In the present study, circulating type 12 antibody in unmistakable amounts was found in approximately 20 per cent of patients without previously known type 12 infections. When those without type 12 antibody, or with only traces of antibody, were vaccinated, however, recall of antibody or boosts in titer to readily measurable levels indicated that more than 50 per cent of the original group actually had been infected previously by streptococcal strains within this prevalent serotype. This result is not unexpected. In recent studies 20 per cent of typable strains isolated from a clinic population of Chicago school children was identified as type 12 (16). Studies in Cleveland, Ohio and in Washington, D.C. have shown approximately the same proportion of type 12 infections $(32,33)$.

In future studies of primary immunization it would be helpful to exclude patients who have been naturally immunized previously with the homologous type of streptococcus. This can be done by preliminary administration of booster doses of vaccine as described in this study. Those who fail to respond to such doses might be considered suitable subjects for studies of primary immunization. A study employing this procedure is in progress.

\section{SUM MARY}

Cell walls of type 12 and type 5 streptococci were tested for antigenicity in human beings with and without previously documented infections of homologous type. Minute doses of $\mathrm{M}$ protein present in streptococcal cell wall vaccines were shown to be capable of producing a secondary type specific immune response in human beings when administered in three or four weekly, well tolerated, subcutaneous or intradermal doses.

Type specific antibodies were boosted or recalled in all patients who previously had had unmistakable primary immune responses to natural infections but whose serum titers had subsequently declined to low levels or disappeared. Secondary responses to vaccination also were elicited readily when antecedent infections had been followed by the appearance of only traces of serum antibody, 
and in some instances, when no circulating antibody had been detected.

Type 12 antibody responses to cell wall vaccine were elicited in 7 of 14 patients who had no prior history of infection with this type and whose preimmunization sera contained either no detectable antibody or only traces thereof.

The implications of these findings with regard to primary artificial immunization against group A streptococci, and the application of booster vaccination as a method for determining previous infection with a given streptococcal serotype are discussed.

\section{ACKNOWLEDGMENTS}

The authors gratefully acknowledge the assistance of the following: Mary Roberts and Robert Gibson, laboratory technicians; Eileen Crawford-Hayes and Joan Martin, research nurses; and Dr. Eloise E. Johnson who participated in the clinical care of the patients.

\section{REFERENCES}

1. Bloomfield, A. L., and Felty, A. R. Prophylactic vaccination against acute tonsillitis. Bull. Johns Hopk. Hosp. 1923, 34, 251.

2. Wilson, M. G., and Swift, H. F. Intravenous vaccination with hemolytic streptococci. Its influence on the incidence of recurrence of rheumatic fever in children. A.M.A. J. Dis. Child. 1931, 42, 42.

3. Collis, W. R. F. Acute rheumatism and haemolytic streptococci. Lancet 1931, 1, 1341.

4. Wasson, V. P., and Brown, E. E. Immunization against rheumatic fever. J. Pediat. 1943, 23, 24.

5. Lancefield, R. C. Cellular constituents of Group A streptococci concerned in antigenicity and virulence in Streptococcal Infections, M. McCarty, Ed. New York, Columbia Univ. Press, 1954, p. 3.

6. Kuttner, A. G., and Lenert, T. F. The occurrence of bacteriostatic properties in the blood of patients after recovery from streptococcal pharyngitis. J. clin. Invest. 1944, 23, 151.

7. Rothbard, S. Bacteriostatic effect of human sera on Group A streptococci, I. Type-specific antibodies in sera of patients convalescing from Group A streptococcal pharyngitis. J. exp. Med. 1945, 82, 93.

8. Watson, R. F., Rothbard, S., and Swift, H. F. Typespecific protection and immunity following intranasal inoculation of monkeys with Group A hemolytic streptococci. J. exp. Med. 1946, 84, 127.

9. Wannamaker, L. W., Denny, F. W., Perry, W. D., Siegel, A. C., and Rammelkamp, C. H., Jr. Studies on immunity to streptococcal infection in man (abstract). A.M.A. J. Dis. Child. 1953, 86, 347.

10. Lancefield, R. C., and Perlmann, G. E. Preparation and properties of type-specific $M$ antigen iso- lated from a Group A, type 1 hemolytic streptococcus. J. exp. Med. 1952, 96, 71.

11. Barkulis, S. S., Walsh, G., and Ekstedt, R. D. Studies of streptococcal cell walls. II. Typespecific antigenicity in rabbits. J. Bact. 1958, 76, 109.

12. Rantz, L. A., Randall, E., and Rantz, H. H. Immunization of human beings with Group A hemolytic streptococci. Amer. J. Med. 1949, 6, 424.

13. Smolens, J., and Warner, H. F. Immunogenic and chemical properties of fractions prepared from 10 types of Group A streptococci. J. Immunol. 1952, 68, 185.

14. Barkulis, S. S., and Hyashi, J. A. Personal communication.

15. Schmidt, W. C. Type-specific antibody formation in man following injection of streptococcal $\mathrm{M}$ protein. J. infect. Dis. 1960, 106, 250.

16. Siegel, A. C., Johnson, E. E., and Stollerman, G. H. Controlled studies of streptococcal pharyngitis in a pediatric population, I. Factors relating to the attack rate of rheumatic fever. New Engl. J. Med. 1961, 265, 559.

17. Siegel, A. C., Johnson, E. E., and Stollerman, G. H. Controlled studies of streptococcal pharyngitis in a pediatric population, II. Behavior of the type specific immune response. New Engl. J. Med. 1961, 265, 566.

18. Griffith, F. The serological classification of Streptococcus pyogenes. J. Hyg. (Lond.) 1934, 34, 542.

19. McCarty, M., and Lancefield, R. C. Variation in group-specific carbohydrate of Group A streptococci. Immunochemical studies on carbohydrates of variant strains. J. exp. Med. 1955, 102, 11.

20. Hess, E. L., and Slade, H. D. An electrophoretic examination of cell-free extracts from various serological types of Group A hemolytic streptococci. Biochim. biophys. Acta 1955, 16, 346.

21. Barkulis, S. S., and Jones, M. F. Studies of streptococcal cell walls. I. Isolation, chemical composition, and preparation of M protein. J. Bact. 1957, 74, 207.

22. Swift, H. F., Wilson, A. T., and Lancefield, R. C. Typing Group A hemolytic streptococci by $M$ precipitin reactions in capillary pipettes. J. exp. Med. 1943, 78, 127.

23. Warburg, O., and Christian, W. Isolierung und Kristallisierung des Gaerungsferments Enolase. Biochem. Z. 1942, 310, 384.

24. Stollerman, G. H., Kantor, F. S., and Gordon, B. D. Accessory plasma factors involved in the bactericidal test for type-specific antibody to Group A streptococci, I. Atypical behavior of some human and rabbit bloods. J. exp. Med. 1958, 108, 475.

25. Stollerman, G. H., and Ekstedt, R. Long chain formation by strains of Group A streptococci in the presence of homologous antiserum: A type-specific reaction. J. exp. Med. 1957, 106, 345. 
26. Stollerman, G. H., Siegel, A. C., and Johnson, E. E. Evaluation of the "long chain reaction" as a means for detecting type-specific antibody to Group A streptococci in human sera. J. exp. Med. 1959, $110,887$.

27. Ekstedt, R. D., and Stollerman, G. H. Factors affecting the chain length of Group A streptococci, II. Quantitative $\mathrm{M}$-anti-M relationships in the long chain test. J. exp. Med. 1960, 112, 687.

28. Lancefield, R. C. Persistence of type-specific antibodies in man following infection with Group A streptococci. J. exp. Med. 1959, 110, 271.

29. Stollerman, G. H. Thermolabile factors in human plasma that promote phagocytosis of virulent Group A streptococci. Trans. Ass. Amer. Phycns 1961, 74, 225.

30. Denny, F. W., Jr., Perry, W. D., and Wannamaker, L. W. Type-specific streptococcal antibody. J. clin. Invest. 1957, 36, 1092.

31. Daikos, G., and Weinstein, L. Streptococcal bacteriostatic antibody in patients treated with peni- cillin. Proc. Soc. exp. Biol. (N. Y.) 1951, 78, 160.

32. James, W. E. S., Badger, G. F., and Dingle, J. H. A study of illness in a group of Cleveland families. XIX. The epidemiology of the acquisition of Group A streptococci and of associated illnesses. New Engl. J. Med. 1960, 262, 687.

33. Cole, R. M. Incidence of type 12 streptococci in school centered populations in Washington, D. C. and Arlington County, Va. Unpublished data.

34. Rammelkamp, C. H., Jr. Glomerulonephritis. Proc. Inst. Med. Chicago 1953, 19, 371.

35. Kevy, S. V., and Lowe, B. A. Streptococcal pneumonia and empyema in childhood. New Engl. J. Med. 1961, 264, 738.

36. Black, P. H., Swartz, M. N., Sharp, J. T., Kunz, L. J., Stokes, J., III, and McFarland, R. B. Severe streptococcal disease. Observations during an epidemic occurring in southern New England, 1958-1959. New Engl. J. Med. 1961, 264, 898. 